\title{
Cognitive and Discourse Peculiarities of Metaphor in A. Lincoln' Discourse
}

\author{
Lada Shadaeva ${ }^{1, *}$, and Galina Kostushkina ${ }^{2}$
}

${ }^{1}$ IRNITU, Institute of Linguistics and multi-cross communication, 664039 Lermontova St., 83, Irkutsk, Russia ${ }^{2}$ Baikal state university, a chair of foreign languages, 664003 Lenin St., 11, Irkutsk, Russia

\begin{abstract}
The process of argumentation aimed at changing hierarchies of values can be called dialectical reasoning. The cognitive feature of metaphor in this type of argumentation in A. Lincoln's discourse is the elimination of differences in the order of the elements of the hierarchy of values in the worldview of the participants in the communication; therefore, the metaphor coordinates the value positions of the communication partners. Discourse feature of metaphor in this type of argument is that it is a tool for creating the following speech strategies according to A. Lincoln: expertise, encouragement, activation of various kinds of social obligations, a propaganda strategy.
\end{abstract}

In the cognitive approach to the study of metaphor, it is perceived as the main link in the assimilation and transfer of knowledge, and we can define the metaphor as the experience of one kind in terms of another experience. Thus, the architectural metaphor of the 19th century, biblical sayings, the provisions of the Declaration of Independence and the wording of the laws of the US Constitution are stereotypes of the motivational level of Lincoln's language personality. As a process, the discourse of A. Lincoln represents statements and appeals organized according to argumentative discourse. In A. Lincoln's argument, the following types are distinguished: logical, generative and dialectical, for which the introduction of the thesis and the presentation of individual arguments of indirect speech acts, assumptions, expressions of opinion, etc., oriented to a picture of the world and knowledge of the addressee, are characteristic. In a broad sense, a communicative strategy can be defined as a type of behavior that is conditioned and correlated with a plan for achieving global and local communication goals within a typical interactive type scenario. In the discourse of A. Lincoln, we can observe the following strategies: examination, promotion, activation of social commitments, propaganda strategy.

The article analyzes the dialectical type of argumentation in the discourse of Lincoln's language personality and examines the role of metaphors in his speech strategies. The process of argumentation aimed at changing hierarchies of values can be called dialectical argumentation [1]. To demonstrate the dialectical type of argumentation, let us analyze the appeal of A. Lincoln to the lyceum students of Springfield, Illinois, dated January 27,1838 . To analyze the argumentative text, we perform a pragmatic-dialectical transformation of the deletion, since not everything in the analyzed text of this appeal is argumentative:
1 (a) "... In the great journal of things happening under the sun, we, the American People, find our account running, under date of the nineteenth century of the Christian era. We find ourselves under the government of a system of political institutions, conducting more essentially to the ends of civil and religious liberty, than any of which the history of former times tells us. ... We toiled not in the acquirement or establishment of them - they are a legacy bequeathed us, by a once hardly, brave, and patriotic, but now lamented and departed race of ancestors. Theirs was the task (and nobly they performed it) to possess themselves, and through themselves, us, of this good land; and to uprear upon its hills and its valleys, a political edifice of liberty and equal rights: 'tis ours only, to transmit these, the former, unprofaned by the foot of an invader; the latter, undecayed by the lapse of time, and untorn by usurpation - to the latest generation that fate shall permit the world to know. As a nation of freemen, we must live through all time, or die by suicide"[2].

Let us turn to the constituent elements of the discourse, events, their participants and the circumstances accompanying the event data, as well as information relating this discourse to events [3]. Such information was unauthorized reprisals of ordinary citizens over the perpetrators of certain crimes. So, for example, in Mississippi, the raging mob hung first the gambler scammers, then hung a group of Negroes suspected of rebellious thoughts and white people accused of colluding with these Negroes, and this lawlessness ended with the massacre of strangers from the neighboring state, their deeds. In another state, a mulatto named Mackintosh was dragged along the whole district of the city, chained to a tree and burned. He was a man who was free from slavery for only one hour, his guilt consisted only in the fact that he was walking in the wrong place and at that hour. The appeal of A. Lincoln is an event of the discourse being analyzed. Participants in this appeal are young people, lyceum students, future law-

* Corresponding author: shadaeva@mail.ru 
abiding citizens of American society. Discussion of citizens' observance of laws and subordination to democratic institutions of a democratic state are those circumstances that accompany this event.

Let us single out the thesis (given) of Lincoln's address:

"In the great journal of things happening under the sun, we, the American People, find our account running, under date of the nineteenth century of the Christian era. We find ourselves under the government of a system of political institutions, conducting more essentially to the ends of civil and religious liberty, than any of which the history of former times tells us", which consists of 2 Assertives (1. In the great journal of things happening under the sun, we, the American People, find ..., 2. We find ourselves ...), demonstrating the state of affairs in the world.

In the first Assertive A. Lincoln uses the expression "In the great journal of things happening under the sun", comparing the course of the history of the country with the conduct of the annals, fixing the events of life. The fixation of events in the annals requires consistency and observance of chronology, these signs are also characteristic of the 'course of history'. The similarity of the signs of various phenomena, such as the course of history and the conduct of the annals, determines our understanding of this metaphorical expression of A. Lincoln. In this part of the text, the metaphor is the thematic type of the metaphorical transfer of the signs of the chronicle $\rightarrow$ the course of history. In this case, A. Lincoln categorizes the course of history in terms of signs of conducting the annals.

In the second assertive speech act, A. Lincoln turns to the fundamental value categories in the picture of the addressee's world, such as civil and religious freedom, political institutions that are the foundations of a democratic state. Appeal in thesis to the universally recognized value categories in the picture of the addressee's world allows one to be sure to A. Lincoln in full acceptability of this thesis.

The propositional form of the thesis is: "According to the course of history, we, American society, live in the 19th century of the Christian era. The foundations of our democratic state are political institutions, civil and religious freedom, the best that have ever been in the history of mankind."

In order to understand the anxious attitude of A. Lincoln to the course of history, which demonstrates the triumph of such foundations of a democratic state as freedom and political institutions, it is necessary to turn to understanding of the society with the puritanical creed of history as a whole, prevalent in the territory of the USA in the era of A. Lincoln.

As we have already noted, in the society with the Puritan faith there was a myth about the contract between the Lord God and all New England. Proceeding from this national agreement, it followed the responsibility of every member of the American society to do God's work (strive for perfection and improve the society that is the guarantor of a true democratic state) in the history of mankind.

Understanding A. Lincoln's concept "history" did not differ from the generally accepted in society understanding. As we have already noted, he believed that the collective activity of the preceding and modern generations is morally significant, because the connection of these generations allows us to improve the rational attitude to life, the final result of which was the historical role of the chosen nation in the universal history.

According to P. Sharodo [P. Charaudeau], in everyday communication, the verbal act is less characteristic of explicit, verbal design. The meaning is often implicit. In the end, every product of speech appears in a semiotically completed form of an explicit, but semantically incomplete lacuna in need of filling in the form of an implicit one [4]. P. Sharodo relates the circumstances of speech to the totality of knowledge of the protagonists of a communicative act: it is simultaneous knowledge about the subject of speech and knowledge about each other, acting as filters for constructing a meaning.

To build the sense of his argument, A. Lincoln uses the knowledge of the religious concept that existed in American society at the turn of the 18 th and 19 th centuries [5]. The main meaning of the utterance is explicated by the talking metaphor of the latest generation, where the grammatical form, or rather the excellent degree of the adjective 'late' and the semantic meaning of this adjective 'the very last' implicate giving the highest degree of significance to the generation of A. Lincoln in the historical mission. In this passage A. Lincoln categorizes his understanding of the significance of the modern generation in terms of the religious concept of the election of the American nation in the world history.

The explicated conclusion of this argument is the phrase: "As a nation of freemen, we must live through all time, or die by suicide". The metaphorical expression of Lincoln's "live through all time, or die by suicide" is a reinterpretation of the actualized value categories expressed by him in the thesis. If in A. Lincoln's thesis refers to such value category of the general picture of the addressee as the perfection of the political institutions and freedoms of a democratic state, then its (value category) preservation guarantees the eternity of the existence of a democratic society, the violation of this value leads to the cessation of the existence of the state. The expression "die by suicide" is part of the concept of "death", where the metaphor "suicide" is one of the ways to escape from life, existence on earth. This expression is a thematic transfer of the "way out of life" $\rightarrow$ "the disappearance of a democratic society". Attention is drawn to the selective character of the grammatical structure in this metaphor. The structure of passive voice, transmitted by the preposition 'by', indicates the feature of the method, indicates the peculiarity of the method of achieving the goal. It seems that the choice of passive pledge by A. Lincoln and the meaning of suicide implicitly expresses the accused's allegation of alleged guilt in the disappearance of the foundations of a democratic society. Here A. Lincoln categorizes the disappearance of the foundations of a democratic society in terms of the concept of "death".

Let us imagine the structure of the argument:

Thesis is: "In the great journal of things happening under the sun, we, the American People, find our account running, under date of the nineteenth century of the Christian era. We find ourselves under the government of a system of political institutions, conducting more essentially to the ends of civil and religious liberty, than any of which the history of former times tells us." 
Base: "We toiled not in the acquirement or establishment of them - they are a legacy bequeathed us, by a once hardly, brave, and patriotic, but now lamented and departed race of ancestors. Theirs was the task (and nobly they performed it) to possess themselves, and through themselves, us, of this good land; and to uprear upon its hills and its valleys, a political edifice of liberty and equal rights: 'tis ours only, to transmit these, the former, unprofaned by the foot of an invader; the latter, undecayed by the lapse of time, and untorn by usurpation - to the latest generation that fate shall permit the world to know."

Conclusion: As a nation of freemen, we must live through all time, or die by suicide".

Any type of argumentation, as noted above, requires a number of mental procedures of a pragmatic nature: the establishment of conformity $\rightarrow$ comparison $\rightarrow$ evaluation $\rightarrow$ the explication of significance. The correspondence is established by A. Lincoln in the thesis in which he appeals to the basic values representing the foundations of a democratic state, such as civil and religious freedom, political institutions in the picture of the addressee's world. Pragmatic procedures for "comparison" and "evaluation" are achieved in A. Lincoln's discourse in an argument consisting of two indirect Assertives, where the second illocutionary act is Directive. A. Lincoln demonstrates the importance of a democratic state, which his modern generation inherited from colonial ancestors (the "comparison" procedure); calls to follow the highest purpose of the nation - to show the world its selectivity in worldly history (homeostatic assessment, i.e., based on the criteria for achieving a specific goal). The explication of significance is expressed by A. Lincoln in the conclusion of the argumentative passage.

We observe a reinterpretation of the thesis by speakers within the given value categories in the picture of the addressee's world, such as freedom, equal rights and political institutions, the significance of the generation, fate, death, which are explicated by A. Lincoln metaphors, "edifice of liberty and equal rights", "to the latest generation", "die by suicide".

Let us turn to the following argumentative paragraph of the analyzed appeal of A. Lincoln, we perform a pragmatic-dialectical transformation of the deletion:

2 (a) "I know the American are much attached to their Government; - I know they would suffer much for its sake; ... Let every American, every lover of liberty, every well-wisher to his posterity, swear by the blood of the Revolution, never to violate in the least particular, the laws of the country; and never to tolerate their violation by others. As the patriots of seventy-six did to the support of the Declaration of Independence, so to the support of the Constitution and Laws, let every American pledge his life, his property, and his sacred honor; - let every man remember that to violate the law, is to trample on the blood of his father, and to tear the character of his own, and his children's liberty. Let reverence for the laws, be breathed by every American mother, to the lisping babe, that prattles on her lap - Let it be taught in schools, in seminaries, and in colleges; - let it be written in Primmers, spelling books, and in Almanacs; - let it be preached from the pulpit, proclaimed in legislative halls, and enforced in courts of justice. And, in short, let it be the political religion of the nation: and Let the old and the young, the rich and the poor, the grave and the gay, of all sexes and tongues, and colors and conditions, sacrifice unceasingly upon its altars".

As a result of the transformation, we removed the nonargumentative element - the description. Let us single out the thesis (given) of the analyzed passage of the appeal of A. Lincoln to the lyceum students of Springfield:

"I know the American are much attached to their Government; - I know they would suffer much for its sake", which is expressed by 2 Assertives (1. I know the American are much attached to their Government; 2. I know they would suffer much for its sake), demonstrating the state of affairs in the world. So, A. Lincoln appeals to the basic value categories in the picture of the addressee's world, such as the location of American citizens to the government of their country, the willingness of citizens to suffer for the sake of its preservation.

As we noted, the modus argument of the argument is incompatible with the states of knowledge and faith. Introduction of the proposition with an explicit mode of knowledge - I know that $\mathrm{P}$ - inevitably leads to the negation of the possibility of discussing its truth [6]. Thus, A. Lincoln uses the verb "to know" in the meaning of the verb "to believe".

The propositional form of the thesis is: "I believe that Americans are very attached to their country. I believe that they would have suffered for the sake of preserving it".

Let us turn to the sequence of arguments presented by A. Lincoln in favor of the expressed thesis. In the above passage of the appeal of A. Lincoln, the arguments have identical syntactic structures using the imperative mood - "Let every American" and "Let it be".

Let us consider the argument 1: "Let every American, every lover of liberty, every well-wisher to his posterity, swear by the blood of the Revolution, never to violate in the least particular, the laws of the country; and never to tolerate their violation by others", expressed by the Directive, whose illocutionary orientation is an attempt on the part of the speaker (A. Lincoln) to ensure that the hearer accomplishes something. The speaker calls the addressee, referring to the fundamental values in his picture of the world, such as freedom, caring for descendants, the sacred memory of the revolution, not to violate the laws of the country and not tolerate such violation by others.

Argument 2: "As the patriots of seventy-six did to the support of the Declaration of Independence, so to the support of the Constitution and Laws, let every American pledge his life, his property, and his sacred honor; - let every man remember that to violate the law, is to trample on the blood of his father, and to tear the character of his own, and his children's liberty", which is presented by Assertive and 2 Directives (1. let every American pledge his life, his property, and his sacred honor; 2 . let every man remember that to violate the law, is to trample on the blood of his father. and to tear the character of his own, and his children's liberty), their combined illocutionary force is directed to an attempt to force the addressee to obey the Constitution and the laws of the country. A. Lincoln refers again to the fundamental values in the picture of the addressee's world, such as the Declaration of Independence, the rights of every member of American society to life, property and honor. The violation of laws, according to A. Lincoln, leads to a break in the continuity of 
generations, the founding fathers and the modern generation. It (violation of laws) threatens the freedom of the future generation. The speaker's opinion finds an explicit expression with the help of expressions to trample on the blood of his father, to tear the character of his own. Metaphors to trample the blood of his father and to tear the character of his own are the categorical transfer of "related blood" $\rightarrow$ "founding fathers" and "own character" $\rightarrow$ "modern generation". The semantic meaning of the verbs "to trample, to tear" also allow us to understand these metaphorical expressions as a "generation continuity gap".

In the expression "his children's liberty," the word 'children' is included in the concept of "the future generation". This metaphor represents the categorical metaphorical transfer of 'children' $\rightarrow$ "the future generation". The semantic meaning of the verb "to tear", i.e., threatening the destruction of the existence of something, allows us to assume the understanding of this expression as "a threat to the freedom of the future generation".

Argument 3: "Let reverence for the laws be breathed by every American mother, to the lisping babe, that prattles on her lap - Let it be taught in schools, in seminaries, and in colleges; - let it be written in Primmers, spelling books, and in Almanacs; - let it be preached from the pulpit, proclaimed in legislative halls, and enforced in courts of justice" expressed by 4 Directives (1. Let reverence for the laws ...; 2. Let it be taught...; 3. let it be written in Primmers ...; 4. let it be preached from the pulpit ...), their combined illocutionary force is directed at the speaker's attempt to force the addressee to act in his interests.

As it is known, association is a natural, spontaneous (mental) binding of two phenomena, representations, objects [7]. The ability of a person to associate is considered innate, it is not difficult to assume that certain models of metaphorization are regularly used by the bearers of all languages and can be classed as typical. So, A. Lincoln associates the submission to the laws of the country with the movement of "reverence", a bow, usually showing respect. He compares the knowledge of the laws of his country with the mother's breathing, which she transmits to a babbling child - "be breathed by every American mother, to the lisping babe, that prattles on her lap". He compares law education with schooling, seminary, and college - "Let it be taught in schools, in seminaries, and in colleges". The design of the written form of laws A. Lincoln associates with writing them in the alphabets, dictionaries and calendars - "let it be written in Primmers, spelling books, and in Almanacs". Teaching the laws of the speaker is compared with preaching, proclaiming them in the legislature, in court decisions - "let it be preached from the pulpit, proclaimed in legislative halls, and enforced in courts of justice". The sequence of various kinds of typical associations aimed at subordination, knowledge, training, writing of the laws of the country, is caused by A. Lincoln's intention to be more convincing in defending his thesis.

Conclusion: "And, in short, let it be the political religion of the nation: and Let the old and the young, the rich and the poor, the grave and the gay, of all sexes and tongues, and colors and conditions, sacrifice unceasingly upon its altars" expressed by 2 Directives (1. let it be the political religion of the nation: 2 . Let the old and the young ...), the combined illocutionary force of which is directed at A. Lincoln's attempt to call his fellow citizens to obey the laws of the country. It can be assumed that the character of the speech acts elected by A. Lincoln in the argument in the argument under discussion demonstrates the openness and lack of reasoning of the argumentation. The metaphor of the political religion of the nation is a thematic transfer of "human belief" $\rightarrow$ "civil obedience". In this case A. Lincoln categorizes the understanding of civil obedience in terms of human belief.

J. David Greenstone [D. J. Greenstone] in his book on American liberalism argues that A. Lincoln's political views were based on two main positions of the liberal party's policy, to which A. Lincoln once belonged. The first position was based on the subordination of society to the political institutions of the state, and the second - the key role of history in achieving decent social goals [8]. Therefore, we can assume that in the hierarchy of values in the world of A. Lincoln, the subordination of society to political institutions was on the first place. Since the value of religious faith occupied the main place in the hierarchy of values in the picture of the addressee's world, Lincoln's appeal to a metaphor of a religious nature is fully justified. In case of inconsistencies in the order of the elements of the hierarchies of values, the purpose of the speaker's argumentation is to eliminate these differences in favor of harmonizing the value positions of the communication partners. Thus, A. Lincoln eliminates differences in the order of the elements of value hierarchies in the world of the addressee, raising the value category of subordination to political institutions to the first place. He defines this value category as a metaphor for the "political religion of the nation". Thus, the speaker agrees the recipient's values with their own.

Since civilian obedience to political institutions A. Lincoln elevates to the rank of "political religion of the nation", the subsequent expression "sacrifice unceasingly upon its altars" is an organic continuation of the religious theme of his argument. Metaphors 'sacrifice and altar' are included in the concept of "religious ritual". A. Lincoln carries out a thematic transfer within the framework of one part of speech, the noun, "religious ritual" $\rightarrow$ "civil obedience". Here A. Lincoln categorizes the understanding of civil obedience to political institutions of power in terms of religious ritual, sacrifice.

In general, the process of A. Lincoln's argument in this passage, aimed at changing the hierarchy of the recipient's values, refers to dialectical reasoning. We represent the structure of this argument as follows.

Thesis is: "I know the American are much attached to their Government; - I know they would suffer much for its sake."

Base:

Argument 1. "Let every American, every lover of liberty, every well-wisher to his posterity, swear by the blood of the Revolution, never to violate in the least particular, the laws of the country; and never to tolerate their violation by others".

Argument 2. "As the patriots of seventy-six did to the support of the Declaration of Independence, so to the support of the Constitution and Laws, let every American pledge his life, his property, and his sacred honor; - let every man remember that to violate the law, is to trample on the blood 
of his father, and to tear the character of his own, and his children's lib."

Argument 3. "Let reverence for the laws, be breathed by every American mother, to the lisping babe, that prattles on her lap - Let it be taught in schools, in seminaries, and in colleges; - let it be written in Primmers, spelling books, and in Almanacs; - let it be preached from the pulpit, proclaimed in legislative halls, and enforced in courts of justice."

Conclusion: "And, in short, let it be the political religion of the nation: and Let the old and the young, the rich and the poor, the grave and the gay, of all sexes and tongues, and colors and conditions, sacrifice unceasingly upon its altars."

Let us turn to the already familiar mental procedures for the dialectical type of reasoning: establishing a correspondence $\rightarrow$ comparison $\rightarrow$ rating $\rightarrow$ explicating the significance. The first pragmatic procedure of "establishing conformity" is achieved by A. Lincoln in an explicated thesis with an appeal to the main value categories in the picture of the addressee's world, such as the location of American citizens to the government of his country, their readiness to suffer for the sake of its preservation. The second pragmatic procedure of "comparison" is reflected by A. Lincoln in arguments (1, $2,3)$ through numerous typical associations aimed at subordination, knowledge, training, writing of the laws of the country. The third "evaluation" procedure is given by the speaker in the conclusion of this argument, which is also an explication of the significance of the speaker's thesis through the metaphor of "the political religion of the nation" and the conceptual metaphor "sacrifice unceasingly upon its altars". We have a homeostatic assessment based on the criteria for achieving a specific goal, in our case the erection of a value category of subordination to political institutions to one of the first places in the hierarchy of values in the world of the addressee through the metaphor "political religion of the nation" [9].

The speaker reinterpreted such value categories as the location of American citizens to the government of his country, the willingness of citizens to suffer for the sake of its preservation in terms of political religion and religious ritual, sacrifices expressed by metaphors "political religion of the nation", "sacrifice unceasingly upon its altars". One of the sources of the variable reflection of the world is the presence, in terms of the content of the statement, of explicit and implicit components. The location of the desired component for the addressee of the meaning in the implicit layer of the utterance is one of the most important ways of speech influence, repeatedly described in the studies of political, advertising and everyday discourse.

Thus, A. Lincoln achieves a positive acceptance of his speech by the addressee, implying the expression and importance of the course of history in the historical drama of the chosen nation:

1(a) "In the great journal of things happening under the sun, we, the American People, find our account running, under date of the nineteenth century of the Christian era. We find ourselves under the government of a system of political institutions, conducting more essentially to the ends of civil and religious liberty, than any of which the history of former times tells us".

The speaker focuses on the responsibility of the addressee for the outcome of this historical drama on the scale of world history of mankind. In this case, we can talk about the speech strategy to activate the social obligation. Further, the speaker refers to such a value of the general picture of the addressee as the perfection of the institutions of a democratic state. Thus, A. Lincoln uses the ability of the addressee to perceive a rational argument, expressed by metaphors "the edifice of liberty", "equal rights", the conceptual metaphor "die by suicide".

This allows us to talk about the speech strategy of the examination in the discourse of A. Lincoln:

26 (1) "We toiled not in the acquirement or establishment of them - they are a legacy bequeathed us, by a once hardly, brave, and patriotic, but now lamented and departed race of ancestors. Theirs was the task (and nobly they performed it) to possess themselves, and through themselves, us, of this good land; and to uprear upon its hills and its valleys, a political edifice of liberty and equal rights: 'tis ours only, to transmit these, the former, unprofaned by the foot of an invader; the latter, undecayed by the lapse of time, and untorn by usurpation - to the latest generation that fate shall permit the world to know. As a nation of freemen, we must live through all time, or die by suicide".

At the same time, using the metaphor "the latest generation", included in the concept of "the nation's choice", the speaker uses a strategy of success, since A. Lincoln attaches special importance to his generation in preserving the foundations of a democratic society in the history of mankind.

In the utterance: 2(a) "Let every American, every lover of liberty, every well-wisher to his posterity, swear by the blood of the Revolution, never to violate in the least particular, the laws of the country; and never to tolerate their violation by others. As the patriots of seventy-six did to the support of the Declaration of Independence, so to the support of the Constitution and Laws, let every American pledge his life, his property, and his sacred honor; - let every man remember that to violate the law, is to trample on the blood of his father and to tear the character of his own, and his children's liberty. Let reverence for the laws, be breathed by every American mother, to the lisping babe, that prattles on her lap - Let it be taught in schools, in seminaries, and in colleges; - let it be written in Primmers, spelling books, and in Almanacs; - let it be preached from the pulpit, proclaimed in legislative halls, and enforced in courts of justice" we can observe the speech strategy of activating the social obligation, since the speaker activates the social obligations of the addressee through numerous typical associations: 1) submission to the laws of the country with a movement, a bow, usually showing reverence - Let reverence for the laws; 2) knowledge of the laws of the country with the breath of the mother, transmitted to her babbling child - be breathed by every American mother, to the lisping babe, that prattles on her lap; 3) teaching laws with schooling, in seminaries, college - Let it be taught in schools, in seminaries, and in colleges; 4) registration of written forms of laws with their writing in the alphabets, dictionaries and calendars - let it be written in Primmers, spelling books, and in Almanacs; 5) teaching laws with preaching, proclamation them in legislative bodies, in court decisions - let it be preached from the pulpit, 
proclaimed in legislative halls, and enforced in courts of justice.

The speaker completes the second, analyzed, excerpt, by erecting the value of subordinating the political institutions of a democratic state to the first place in the hierarchy of values in the world of the addressee by means of religious metaphors "the political religion of the nation", "sacrifice unceasingly upon its altars":

26 (1) "And, in short, let it be the political religion of the nation: and let the old and the young, the rich and the poor, the grave and the gay, of all sexes and tongues, and colors and conditions, sacrifice unceasingly upon its altars." In this case, we can again talk about the speech strategy of the act of reviving the social obligation of the addressee.

Thus, in the dialectical type of A. Lincoln's argument, we observe the following speech strategies: examination, promotion and activation of social obligations [10].

\section{References}

1. A. N. Baranov, Cognitive Mechanisms of Ontologization of Knowledge in the Mirror of a Language, Trudy of Art. Intel. 793. p. 21-39 (1988)

2. A. Lincoln, Address to the Young Men's Lyceum of Springfield, Illinois. S. and W. 1832-1858. V. I, p. 28 37 (1989)

3. T. A. van Dijk, Semantic Discourse Analysis, Handbook of D. A. 2. p. 103-125 (1985)

4. P. Charaudeau, Grammaire du sens et de l'expression. (Hachette Education, Paris, 1992)

5. A. A. Genis, the Tower of Babel, F. L. 9. p. 10-216 (1996)

6. P. K. Kaburise, Speech act theory and communication. (University of Pretoria, Pretoria, 2005)

7. M. Minsky, Frames for representation of knowledge. (Massachusetts Institute of Technology Cambridge, Cambridge, 1974)

8. D. J Greenstone, The Lincoln Persuasion. Remaking American Liberalism. (Princeton University Press, Princeton, 1993)

9. P. N. Hear, Descriptiveness and evaluation, L. pragm. 16. p. 183-195 (1985)

10. R. D. Rieke, Argumentation and the decision making process. (Macmillan Publishing Co., N-Y, 1975) 